\title{
The oldest hexanchiform shark from the Southern Hemisphere (Neoselachii; Early Cretaceous, Antarctica)
}

\author{
ALBERTO LUIS CIONE ${ }^{1 *}$ and FRANCISCO MEDINA ${ }^{2}$ \\ ${ }^{I}$ División Paleontología de Vertebrados, Museo de La Plata, 1900 La Plata, Argentina \\ ${ }^{2}$ Departamento de Ciencias Geológicas, Facultad de Ciencias Exactas y Naturales, Universidad de Buenos Aires, \\ Ciudad Universitaria, 1428 Buenos Aires, Argentina \\ *acione@museo.fcnym.unlp.edu.ar
}

\begin{abstract}
The oldest record of the hexanchiform sharks from the Southern Hemisphere and the second chondrichthyan report known from Carboniferous to Early Cretaceous beds in Antarctica is given. The material was collected in late Aptian rocks of the Kotick Point Formation outcropping in the western part of James Ross Island, near Antarctic Peninsula. It consists of an isolated tooth assignable to a hexanchiform different from the other described genera. The tooth shows putative plesiomorphic cusp (few cusps, no serrations) and apomorphic root characters (relatively deep, quadrangular). It could be related to a species close to the origin of Hexanchus (unknown in beds older than Cenomanian).
\end{abstract}

Received 6 December 2008, accepted 23 March 2009

Key words: Aptian, Hexanchiformes, James Ross Island, Neoselachii

\section{Introduction}

The chondrichthyan fossil record from Antarctica is scant and patchy. It is restricted to some Devonian primitive sharks (Young 1982), a palaeospinacid tooth from Early Cretaceous beds (Kriwet 2003), some sharks, rays, and holocephalan from late Cretaceous beds of Ross, Vega, and Seymour Islands, and especially the diverse record of the Eocene La Meseta Formation of Seymour Island (Cione et al. 1977, Welton \& Zinsmeister 1980, Cione \& Medina 1987, Grande \& Chatterjee 1987, Richter \& Ward 1990, Long 1992, 1994, Cione \& Reguero 1994, 1998, Klug et al. 2005).

Hexanchiformes present a single dorsal fin without preceding spine, more than five branchial slits, and peculiar teeth. We here follow the definition of Carvalho (1996) which includes Clamydoselachus in the order. Hexanchiformes ranges from the Sinemurian (lower Jurassic) to the Recent (Underwood \& Ward 2004). Presently, they are distributed almost worldwide but in the lower Cretaceous they are known from very few localities in Europe and Australia (Cappetta 1987, 1990, Thies 1987, Siverson 1997). According to Thies \& Reif (1985), Hexanchiformes (excluding Clamydoselachus) are the first true "meat-cutters" among the neoselachians and its appearance could have been stimulated by the rise of the big amphibious and marine reptiles during the Triassic. In this paper, a peculiar hexanchiform tooth from Early Cretaceous beds of the James Ross Island is described.

\section{Stratigraphical and geographical provenance}

James Ross Island is near the north-eastern part of the Antarctic Peninsula. During the Mesozoic to Tertiary a volcanic arc was located in the Antarctic Peninsula, while a back-arc basin (the James Ross Island or Larsen basin) developed to the east. Cretaceous strata on James Ross Island comprise a thick succession divided into two major lithostratigraphic units: the Gustav Group (Ineson et al. 1986) and the Marambio Group (Olivero et al. 1986).

The Cretaceous deposits of the Gustav Group are exposed in western James Ross Island forming a belt of about $50 \mathrm{~km}$ in length (Fig. 1). The group includes, from base to top, the following stratigraphic units: Lagelius Point Formation, Kotick Point Formation, an unnamed unit, Whisky Bay Formation, and Hidden Lake Formation (Ineson et al. 1986, Medina \& Riccardi 2005). The group is characterized by thick sequences of conglomerates, breccias, sandstones, and mudstones that show marked lateral and vertical facies variations.

The tooth here described was collected about $2.1 \mathrm{~km}$ south-west of Kotick Point. In this locality two sections (Fig. 1, A' \& A) have been measured along a succession, about $330 \mathrm{~m}$ thick ascribed to the Kotick Point Formation (Fig. 1). The base is not exposed.

The lowest $170 \mathrm{~m}$, studied along Section A' and the lower part of the succession exposed in Section A, are characterized by grey silty mudstones and conglomerates with minor fine sandstone intercalations. Late Aptian ammonoids are present in different levels. Sanmartinoceras sp. and Pseudosilesites russoi (Leanza) occur between 124-160 m, "Lithancylus" cf. guanacoense (Leanza) between 94-192 m, and species of genera Australiceras and Tropaeum between $65-156 \mathrm{~m}$. The shark tooth level is located at 102 above the base of the section (Fig. 1).

The following $75 \mathrm{~m}(170-245 \mathrm{~m})$ are composed by mudstones and siltstones, with subordinate intercalations 

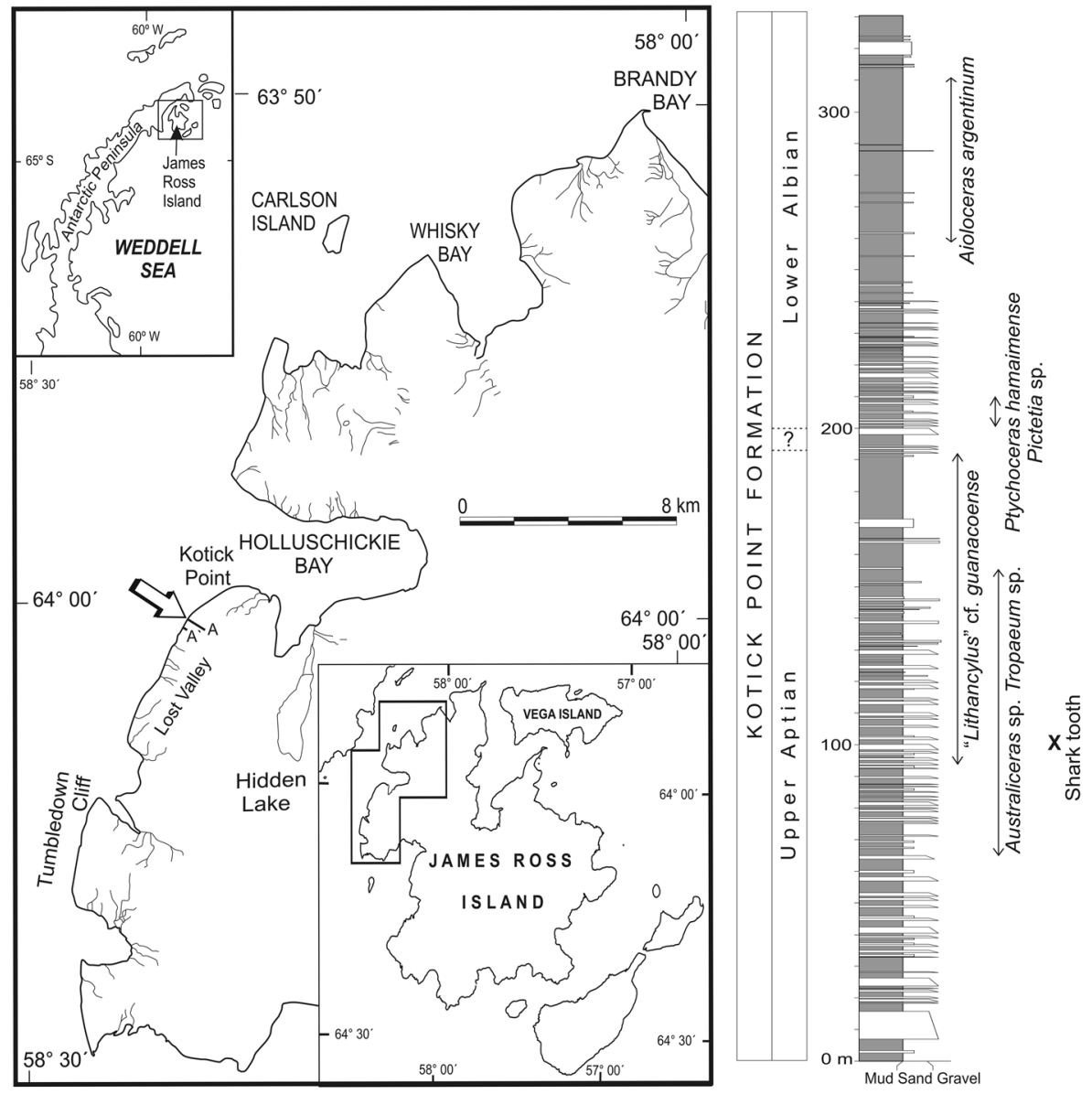

of fine sandstones and conglomerates. The overlaying $85 \mathrm{~m}$ $(245-330 \mathrm{~m})$ comprise massive dark grey siltstones and mudstones with intercalations of fine-grained sandstones and occasional thin conglomerates. The upper fauna $(197-330 \mathrm{~m})$ of the Kotick Point Formation is dominated by molluscs. They are locally abundant but occur in low diversity. Some of the molluscs, figured and described by Medina et al. (1983, 2003), Medina \& Riccardi (2006), and Medina (2007), are characteristic of the Lower Albian.

\section{Age}

The shark tooth described here from Kotick Point is certainly of Late Aptian age. Species of the genus Australiceras and Tropaeum are characteristic of the Aptian. All of these taxa occur in the section where the tooth was found. This interval is securely dated as Late Aptian by the occurrence of the heteromorph ammonite "Lithancylus" cf. guanacoense which is particularly important because it is restricted to the Upper Aptian Australiceras hallei Assemblage Zone and Peltocrioceras deeckei Assemblage Zone in Patagonia (Medina \& Riccardi 2005).
Fig. 1. Maps showing the position of the section measured (A, $\left.\mathrm{A}^{\prime}\right)$ through the Kotick Point Formation. The arrow indicates the level where the shark tooth was found.

\section{Systematics}

Neoselachii

Hexanchiformes

Family indeterminated

Fig. 2

Material and repository: MLP 98-XI-20-1. An almost complete lower right lateral tooth. Departamento Paleontología de Vertebrados, Museo de La Plata, 1900 La Plata, Argentina.

Geographic and stratigraphic provenance: James Ross Island, Antarctic Peninsula; Kotick Point Formation, Upper Aptian.

Collector: The material was collected by Francisco Medina in 1997.

Description: Total length (TL): $13.8 \mathrm{~mm}$, maximum height $(\mathrm{MH}): 7.3 \mathrm{~mm}$, maximum root height $(\mathrm{MRH}): 3.8 \mathrm{~mm}(\mathrm{TL} /$ $\mathrm{MRH}=3.6, \mathrm{TL} / \mathrm{MH}=1.9$ ).

The crown is labiolingually compressed and the enameloid is smooth. There is a large distally inclined main cusp followed by three (perhaps four) distally inclined cusplets. Main cusp and distal cusplets present the same angle what indicates that it is a lower tooth. The main cusp has a long mesial smooth cutting edge. The upper part of 


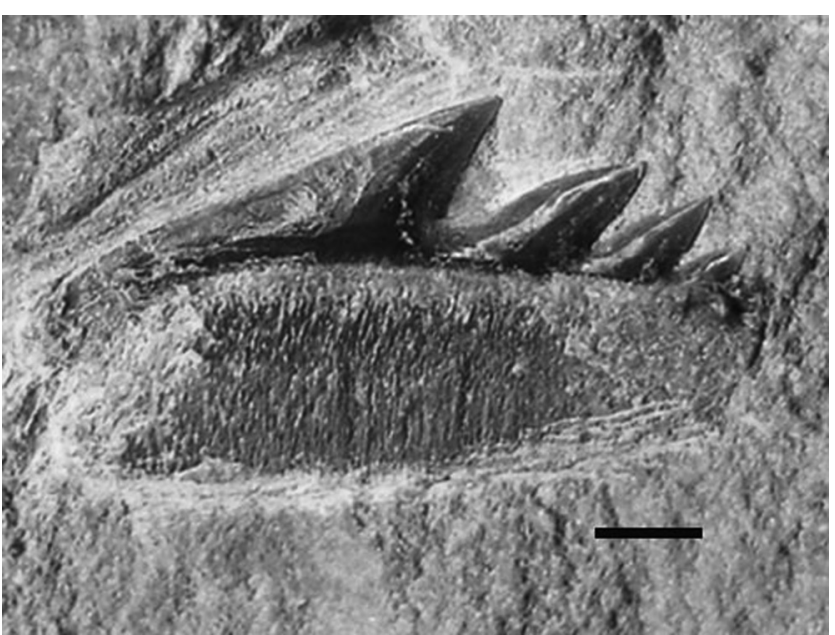

Fig. 2. MLP 98-XI-20-1. Lower right lateral tooth. The line is $2 \mathrm{~mm}$.

the main cusp mesial cutting edge is convex, the middle part of the mesial cutting edge and the distal cutting edge are concave. The anteriormost part of the tooth is missing but there are not mesial cusplets or serrations of any kind. Distal cusps decrease gradually in size and present convex mesial and distal cutting edges.

The analaucorhize root is labiolingually compressed, tabular and deep. The lingual longitudinal protuberance is straight and well developed. Root-crown junction occurs in the thickest part of the tooth and it is gently convex.

\section{Discussion}

The following combination of characters allows us to distinguish the present material from teeth of other recent and fossil Hexanchiformes such as Notidanodon, Pachyhyexanchus, Heptranchias, Notorynchus, Clamydoselachus, Weltonia, Welcommia, "Eonotidanus" serratus (Kriwet \& Klug 2004), Paranotidanus, Notidanoides pockrandti, and typical Hexanchus (see Cappetta 1987, Ward \& Thies 1987, Cione \& Reguero 1994, Cione 1996, Underwood \& Ward 2004): reduced mesiodistal length; crown labiolingually compressed; absence of mesial cusplets or serrations; moderately developed main cusp; three or four distal cusps, gradually decreasing in size and with convex mesial and distal cutting edges; deep, tabular, and compressed root; lingual longitudinal protuberance straight and well developed, close to the root-crown junction. It also differs from the Jurassic-Cretaceous Pseudonotidanus, which combines characters of Hexanchiformes and Synechodontiformes (Underwood \& Ward 2004, Kriwet \& Klug 2004).

MLP 98-XI-20-1 shows putative apomorphic characters such as a deep, quadrangular $(\mathrm{TL} / \mathrm{MRH}=3.6)$ and compressed root with primitive characters such as few cusps and no serrations. The crown is relatively similar to that of Notidanoides muensteri figured by Kriwet \& Klug
(2004) from the Tithonian of Germany. However, the root is not similar to coeval sharks such as Notidanodon lanceolatus and Notidanoides pockrandti and Jurassic species. On the contrary, the root is similar to that of some teeth of Notorynchus aptiensis, and other younger genera. Actually, except for the small number of cusps, it resembles Hexanchus lower teeth. Hexanchus has not been certainly recognized in beds older than Cenomanian (Underwood \& Mitchell 1999). Previous Jurassic records appear to have been misidentifications.

The material is the oldest record of Hexanchiformes from the Southern Hemisphere. There has been some argument as to whether the Devonian shark Mcmurdodus from Antarctica and Australia belongs in Hexanchiformes (Young 1982, Turner \& Young 1987). However, this assignment was discarded by Burrow et al. (2008). The oldest certain record of Hexanchiformes is early Jurassic (de Beaumont 1960). The oldest reliable record of a recent genus is represented by the species Notorynchus aptiensis from the lower Cretaceous. Siverson (1997) described the occurrence of Notidanodon lanceolatus from the Albian of Australia. This is the only other hexanchiform (although younger) report from southern continents from the lower Cretaceous. Besides, the only other record of a shark from Early Cretaceous beds of Antarctica is a tooth from the Spartan Glacier Formation of the Fossil Bluff Group of Alexander Island, Antarctic Peninsula which was assigned to Palaeospinacidae, an extinct group of neoselachian sharks (Kriwet 2003). This tooth was previously supposed to have been recovered from Middle Jurassic strata. However, sedimentation of the Spartan Glacier Formation was from the Valangian to Aptian. Consequently, an Early Cretaceous age was assigned to the specimen although its exact stratigraphical horizon is unknown (Kriwet 2003).

Thies (1987) suggested that the Early Cretaceous cow sharks were distributed according to temperature: Notidanoides pockrandti and Notorynchus aptiensis were presumably Tethyan faunal elements whereas Notidanodon lanceolatus would be a Boreal faunal form. Jurassic hexanchiforms were found also in these areas. Notwithstanding that the Jurassic and Early Cretaceous elasmobranch record for the Southern Hemisphere is extremely reduced (e.g. Siverson 1997, Cione 1999, Perea et al. 2001, Cione et al. 2002, Kriwet 2003), the occurrence of $N$. lanceolatus in Australia (Siverson 1997) would confirm the bipolar biogeographical pattern for Notidanodon hypothesized by Cione (1996).

\section{Acknowledgements}

We would like to thank the Agencia Nacional de Promoción Científica y Tecnológica, Consejo Nacional de Investigaciones Científicas y Técnicas, and Universidad Nacional de La Plata, for permanent financial support. To Dr C.A. Rinaldi, former Director of the Instituto Antártico Argentino, and Fuerza Aérea Argentina, for field support. 
We also thank the reviewers John Long and Jürgen Kriwet for valuable comments.

\section{References}

Burrow, C., Hovestadt, D.C., Hovestadt-Euler, M., Turner, S. \& YounG, G.C. 2008. New information on the Devonian shark Mcmurdodus, based on material from western Queensland, Australia. Acta Geologica Polonica, 58, 155-163.

CAppetta, H. 1987. Chondrichthyes II. Stuttgart: Gustav Fischer, 193 pp.

CAppetta, H. 1990. Hexanchiforme nouveau (Neoselachii) du Crétacé inférieur du sud de la France. Palaeovertebrata, 20, 33-54.

Carvalho, M.R. 1996. Higher-level elasmobranch phylogeny, basal Squaleans, and Paraphyly. In Stiassny, M., Parenti, L. \& Johnson, G., eds. Interrelationships of fishes. San Diego, CA: Academic Press, 35-62.

Cione, A.L. 1996. The extinct Notidanodon lineage (Neoselachii, Hexanchiformes). In Arratia, G. \& Viohl, G., eds. Proceedings of the International Symposium Mesozoic Fishes: Systematics and Palaeoecology; Eischtädt, 1993. München: Alemania, 63-72.

Cione, A.L. 1999. First report of a Jurassic ray outside of Europe. In Arratia, G. \& Schultze, H.P., eds. Mesozoic fishes - systematics and fossil record 2. München: Verlag Dr Friedrich Pfeil, 21-28.

Cione, A.L. \& Medina, A.F. 1987. A record of Notidanodon pectinatus (Chondrichthyes, Hexanchiformes) in the Upper Cretaceous of the Antarctic Peninsula. Mesozoic Research, 1, 79-88.

Cione, A.L., Mennucci, J.A., Acosta, C.H. \& Cocca, S. 2002. The first Triassic-Jurassic shark of South America. Neues Jahrbuch für Geologie und Paläontologie, Monatshefte, 2002, 9-18.

Cione, A.L. \& Reguero, M. 1994. New records of the sharks Isurus and Hexanchus from the Eocene of Seymour Island, Antarctica. Proceeding of the Geologist's Association, 105, 1-14.

Cione, A.L. \& Reguero, M. 1998. A middle Eocene basking shark (Lamniformes, Cetorhinidae) from Antarctica. Antarctic Science, 10, $83-88$.

Cione, A.L., Valle, R., Rinaldi, C. \& Tonni, E.P. 1977. Nota preliminar sobre los pinguinos y tiburones del Terciario inferior de la isla Vicecomodoro Marambio, Antártida. Contribuciones Cientificas del Instituto Antártico Argentino, 213, 3-21.

De Beaumont, G. 1960. Contribution a l'étude des genres Orthacodus Woodw. et Notidanus Cuv. (Selachii). Mémoires Suisses de Paléontologie, 77, 1-46.

Grande, L. \& Chatterjee, S. 1987. New Cretaceous fish fossils from Seymour Island, Antarctica Peninsula. Palaeontology, 30, 829-837.

Ineson, J.R., Crame, J.R. \& Thomson, M.R.A. 1986. Lithostratigraphy of the Cretaceous strata of west James Ross Island, Antarctica. Cretaceous Research, 7, 141-159.

KLUG, S., Kriwet, J., LiRio, J. \& NúÑEZ, H. 2005. Synechodontiform sharks from the late Cretaceous of Antarctica (Chondrichthyes, Neoselachii). Extended Abstracts of the Fourth International Meeting on Mesozoic Fishes-Systematic, Homology, and Nomenclature. Madrid: Universidad Autonoma de Madrid, 133-135.

KRIWET, J. 2003. First record of an Early Cretaceous shark (Chondrichthyes, Neoselachii) from Antarctica. Antarctic Science, 15, 507-511.

Kriwet, J. \& Klug, C. 2004. Late Jurassic selachians (Chondrichthyes, Elasmobranchii) from southern Germany: re-evaluation on taxonomy and diversity. Zitteliana, A44, 123-141.
LonG, D. 1992. The shark fauna from La Meseta Formation (Eocene), Seymour Island, Antarctic Peninsula. Journal of Vertebrate Paleontology, 12, 11-32.

LoNG, D.J. 1994. Quaternary colonization of Paleogene persistence?: historical biogeography of skates (Chondrichthyes: Rajidae) in the Antarctic ichthyofauna. Paleobiology, 20, 215-228.

Medina, F.A. 2007. Inocerámidos albianos de la Isla James Ross, Antártida. VI Argentine and III Latin American Symposium on Antarctic Research, 1-4. Available at /www.dna.gov.ar/ingles/ciencia/ santar07/index.htm

Medina, F.A. \& Riccardi, A.C. 2005. Desmoceratidae, Silesitidae and Kossmaticeratidae (Ammonitina) from the Upper Aptian-Albian of Patagonia (Argentina). Revue de Paléobiologie, 24, 251-286.

Medina, F.A. \& Riccardi, A.C. 2006. Desmoceratidae and Silesitidae (Ammonitida) from the Aptian-Albian of Antarctica. Neues Jahrbuch für Geologie und Paläontologie, Abhandlungen, 242, 289-327.

Medina, F.A., Rinaldi, C.A., Del Valle, R.A. \& Baldoni, A.M. 1983. Edad de la Formación Lower Kotick Point en la isla James Ross, Antártida. Ameghiniana, 19, 263-272.

Medina, F.A., Riccardi, A.C. \& Ghiglione, M. 2003. First record of the Albian ammonite Aioloceras Whitehouse in Antarctica. Alcheringa, 27, $85-91$.

Olivero, E.B., Scasso, R.A. \& Rinaldi, C.A. 1986. Revisión of the Marambio Group, James Ross Island, Antarctica. Contribuciones del Instituto Antártico Argentino, 331, 1-29.

Perea, D., Ubilla, M., Rojas, A. \& Goso, C. 2001. The west Gondwana occurrence of the hybodontid shark Priohybodus, and the Late Jurassic-Early Cretaceous age of Tacuarembó Formation, Uruguay. Palaeontology, 44, 1227-1235.

Richter, M. \& WARD, D.J. 1990. Fish remains from the Santa Marta Formation (Late Cretaceous) of James Ross Island, Antarctica. Antarctic Science, 2, 67-76.

Siverson, M. 1997. Sharks from the mid-Cretaceous Gearle Siltstone, southern Carnarvon basin, western Australia. Journal of Vertebrate Paleontology, 17, 453-465.

Thies, D. 1987. Palaeoecology of Lower Cretaceous cow sharks (Neoselachii, Hexanchiformes). Paläontologische Zeitung, 61, 133-140.

Thies, D. \& ReIF, W.E. 1985. Phylogeny and evolutionary ecology of Mesozoic Neoselachii. Neues Jahrbuch für Geologie und Palaeontologie, Abhandlungen, 169, 333-361.

Turner, S. \& Young, G.C. 1987. Shark teeth from the Early-Middle Devonian Cravens Peak Beds, Georgina Basin, Queensland. Alcheringa, 11, 233-244.

Underwood, C.J. \& Mitchell, S.F. 1999. Albian and Cenomanian selachian assemblages from north-east England. Special Papers in Palaeontology, 60, 9-56.

Underwood, C.J. \& WARD, D.J. 2004. Neoselachian sharks and rays from the British Bathonian (Middle Jurassic). Palaeontology, 47, 447-501.

WARD, D.J. \& Thies, D. 1987. Hexanchid shark teeth (Neoselachii, Vertebrata) from the Lower Cretaceous of Germany and England. Mesozoic Research, 1, 89-106.

Welton, B. \& Zinsmeister, W. 1980. Eocene neoselachians from the La Meseta Formation, Seymour Island, Antarctic Peninsula. Contributions in Science, 329, 1-10.

YounG, G. 1982. Devonian sharks from south-eastern Australia and Antarctica. Palaeontology, 25, 817-843. 